\title{
Bucky Tubes Induce Oxidative Stress Mediated Cell Death in Human Lung Cells
}

\author{
Jaya Singhal, ${ }^{1}$ Surinder P. Singh, ${ }^{2}$ Stalin Karuppiah, ${ }^{2}$ and Alok K. Pandey ${ }^{1,3}$ \\ ${ }^{1}$ Nanomaterial Toxicology Laboratory, CSIR, Indian Institute of Toxicology Research, P. O. Box 80, \\ Mahatma Gandhi Marg, Lucknow 226001, India \\ ${ }^{2}$ CSIR, National Physical Laboratory, Dr. K. S. Krishnan Marg, New Delhi 110012, India \\ ${ }^{3}$ Academy of Scientific and Innovative Research, New Delhi, India \\ Correspondence should be addressed to Alok K. Pandey; pandeyalok2006@gmail.com
}

Received 23 July 2014; Accepted 20 August 2014

Academic Editor: Rishi Shanker

Copyright (C) 2015 Jaya Singhal et al. This is an open access article distributed under the Creative Commons Attribution License, which permits unrestricted use, distribution, and reproduction in any medium, provided the original work is properly cited.

\begin{abstract}
Unique physicochemical properties of carbon nanomaterials (CNMs) have opened a new era for therapeutics and diagnosis (known as theranostics) of various diseases. This exponential increase in application makes them important for toxicology studies. The present study was aimed at exploring the toxic potential of one of the CNMs, that is, bucky tubes (BTs), in human lung adenocarcinoma (A549) cell line. BTs were characterised by electron microscopy (TEM), dynamic light scattering (DLS), Fourier transform spectroscopy (FTIR), and X-ray diffraction (XRD). Flow cytometric study showed a concentration and time dependent increase in intracellular internalization as well as reduction in cell viability upon exposure to BTs. However, a significant increase in intracellular reactive oxygen species (ROS) production was observed as evident by increased fluorescence intensity of $2^{\prime}, 7^{\prime}$ dichlorofluorescein (DCF). BTs induced oxidative stress in cells as evident by depletion in glutathione with concomitant increase in lipid peroxidation with increasing concentrations. A significant increase in micronucleus formation and apoptotic cell population and loss of mitochondrial membrane potential (MMP) as compared to control were observed. Moreover, in the present study, BTs were found to be mild toxic and it is encouraging to conclude that BTs having outer diameter in the range of 7-12 nm and length $0.5-10 \mu \mathrm{m}$ can be used for theranostics.
\end{abstract}

\section{Introduction}

Nanotechnology has developed tremendously in past few decades which lead to the discovery and production of various nanomaterials (NMs), that is, metallic (silver and gold) and metallic oxide nanoparticles $\left(\mathrm{ZnO}\right.$ and $\left.\mathrm{TiO}_{2}\right)$, quantum dots and carbon nanomaterials. These NMs find potential applications in diverse areas including physical, chemical, and biological sciences such as cosmetics, food packaging industries, electronics, medicines, and biomedical engineering [1-3]. In spite of wide applications, these NMs have critically drawn concerns towards their potential adverse effects to human beings.

Carbon nanotubes (CNTs) are the distinct form of carbon based nanomaterials (CNMs) comprised of single or concentrically stacked graphene sheets rolled seamlessly, showing astonishing structural and physicochemical properties. These have been explored for diverse applications ranging from electronics to biomedical applications in applied sciences such as nanoinjectors, tissue engineering, drug delivery, gene therapy, and biosensor technology [4-8]. The aforementioned exponential increase in applications of CNTs raised concerns towards the occupational threats on exposure of CNTs which has been discussed in several reports [9].

An occupational survey on exposure of engineered nanoparticles suggested that the workers got chronic obstruction and pulmonary and cardiac diseases due to exposure of nanoparticles [10]. It can be said that on exposure nanoparticles may be accumulated in different organs upon systemic circulation and will end up as waste; further their subsequent degradation may liberate particles into the environment where they may remain or circulate in food web [11, 12]. Previous studies dealing with both in vitro and in vivo cellular targets showed the toxic effects of MWCNTs on aquatic 
lives and some other species $[13,14]$. The consumption of nanoparticles follows the demand and supply rule which ultimately pose a risk on environment as well as on society and become major concern [15].

According to previous reports, MWCNTs were found to be immunotoxic when exposed to murine macrophages for $16 \mathrm{~h}, 24 \mathrm{~h}$, and $32 \mathrm{~h}(0-100 \mu \mathrm{g} / \mathrm{mL})$ [16]. Another group reported that MWCNTs were cytotoxic and cause oxidative stress in dose dependent manner $[17,18]$.

Several groups suggested that inhalation is the primary route of exposure of MWCNTs and hence induces pulmonary toxicity [19-22]. Recently it was observed that instillation of MWCNTs via oropharyngeal exposure route impairs pulmonary functioning by inducing epithelial damage in C56B1/6 mice due to the development of IL-33 dependent Th2 associated inflammatory response [23]. Another inhalation study reported that C57BL/6J mice exposed to MWCNTs aerosol $\left(10 \mathrm{mg} / \mathrm{m}^{3}, 5 \mathrm{~h} /\right.$ day) for $2,4,8$, or 12 days showed pulmonary inflammation and damage with rapid development of pulmonary fibrosis in time dependent manner [24].

Therefore, keeping in view the above mentioned reports regarding pulmonary toxicity, present study was designed to examine the toxic effect of bucky tubes [BTs, a type of multiwall carbon nanotubes] on human lung alveolar cell lines (A549).

\section{Materials and Methods}

2.1. Chemicals. Bucky tubes (CAS number 308068-56-6), propidium iodide (PI), 2,7-dichlorofluorescein diacetate (DCFDA) dye, 5,5',6,6'-tetrachloro-1,1 $1^{\prime} 3^{\prime} 3^{\prime}$-tetraethylbenzimidazolecarbocyanine iodide (JC-1) dye, ethidium bromide (EtBr), Triton X-100, 5, $5^{\prime}$-dithiobisnitrobenzoic acid (DTNB), and glutathione (GSH) were purchased from Sigma Chemical Co. Ltd. (St. Louis, MO, USA). Phosphate buffered saline $\left(\mathrm{Ca}^{+2}, \mathrm{Mg}^{+2}\right.$ free; $\left.\mathrm{PBS}\right)$, Dulbecco's modified eagle medium : nutrient mixture F-12 (Ham) (1:1) powder (DMEM F-12), trypsin-EDTA, fetal bovine serum (FBS), trypan blue, antibiotic, and antimycotic solution $(10,000 \mathrm{U} / \mathrm{mL}$ penicillin, $10 \mathrm{mg} / \mathrm{mL}$ streptomycin, and $25 \mu \mathrm{g} / \mathrm{mL}$ amphotericin-B) were purchased from Life Technologies Pvt. Ltd. (New Delhi, India). All other chemicals were obtained locally and were of analytical reagent grade. All cell culture plastic wares were obtained from Thermo Scientific Nunc (Rochester, New York).

2.2. Characterization of BTs. The particles were characterized by transmission electron microscopy (TEM), dynamic light scattering (DLS), Fourier transform spectroscopy (FTIR), and X-ray diffraction (XRD).

2.2.1. Transmission Electron Microscopy (TEM). Electron microscopy was carried out for the assessment of morphology and size of BTs. Samples were prepared by suspending BTs in Milli-Q water at a concentration of $25 \mu \mathrm{g} / \mathrm{mL}$ and a drop of nanoparticle suspension was put on the formvar coated copper grids. Then, grids were dried properly and examined under the TEM at an accelerating voltage of $80 \mathrm{kV}$ on TechnaiG2 spirit instrument (FEI, The Netherlands).
2.2.2. Dynamic Light Scattering (DLS). Bucky tubes were suspended in complete growth medium, that is, DMEMF12 supplemented with $10 \%$ fetal bovine serum (FBS) at a concentration of $150 \mu \mathrm{g} / \mathrm{mL}$, and probe sonicated (Sonics \& Material Inc., New Town, CT, USA) at 30 watt for total $10 \mathrm{~min}$ ( $2.5 \mathrm{~min}$ pulse on and $1 \mathrm{~min}$ pulse off) and allowed to cool down at room temperature. The average hydrodynamic diameter and zeta potential of BTs were determined using dynamic light scattering and phase analysis light scattering, respectively, using a Zetasizer Nano-ZS, Model ZEN3600 (Malvern Instruments Ltd., Malvern, UK).

2.2.3. Fourier Transform Spectroscopy (FTIR) Analysis of BTs. FTIR analysis of BTs has been performed with the scan range $400-4000 \mathrm{~cm}^{-1}$ at the resolution of $8 \mathrm{~cm}^{-1}$ using ATR accessory on Agilent Cary 630 FTIR spectrometer.

2.2.4. X-Ray Diffraction (XRD) Analysis of BTs. Powder Xray diffraction of BTs has been done using Rigaku Miniflex-II bench top X-ray diffractometer with tube voltage of $30 \mathrm{KV}$.

\subsection{In Vitro Toxicity Assessment}

2.3.1. Cell Culture and BTs Exposure. The human lung epithelial cells (A549) were purchased from the National Centre for Cell Sciences (NCCS), Pune, India, and maintained in DMEMF-12 $(1: 1)$ medium supplemented with $10 \%$ heat inactivated FBS, $0.2 \%$ sodium bicarbonate, and $1 \%$ antibiotic and antimycotic solution at $37^{\circ} \mathrm{C}$ under a humidified atmosphere of $5 \% \mathrm{CO}_{2}$.

A549 cells were cultured in complete medium having all supplements and were harvested at $80-85 \%$ confluency using $0.25 \%$ trypsin-EDTA solution and were seeded at a density of $1 \times 10^{4}$ cells $/ \mathrm{mL} /$ well in a flat bottom 96 -well plate, $1 \times$ $10^{5}$ cells $/ \mathrm{mL} /$ well in a 12 -well plate, and $2 \times 10^{5}$ cells $/ \mathrm{mL}$ in a 6-well plate and culture flasks according to the need of the experiment. After $22 \mathrm{~h}$ of seeding, cells were incubated with varying concentrations of BTs $(1,10,25,50$, and $100 \mu \mathrm{g} / \mathrm{mL})$ for different time points $(1 \mathrm{~h}, 3 \mathrm{~h}, 6 \mathrm{~h}$, and $24 \mathrm{~h})$ at $37^{\circ} \mathrm{C}$; cells without nanoparticles were taken as control.

\subsubsection{Intracellular Internalization of Carbon Nanoparticles.} The uptake of BTs using flow cytometry was measured according to the method of Suzuki et al. [25]. For assessing intracellular internalization of BTs, cells were seeded in 12 -well cell culture plates and after $22 \mathrm{~h}$ of seeding, cells were exposed to different concentrations of BTs $(1,10,25$, 50 , and $100 \mu \mathrm{g} / \mathrm{mL}$ ) for $6 \mathrm{~h}$ and $24 \mathrm{~h}$. After completion of exposure time, the culture medium containing nanoparticles was removed and cells were harvested using $0.25 \%$ trypsinEDTA. The cells were then centrifuged at $1200 \mathrm{rpm}$ for $10 \mathrm{~min}$ and the pellet was resuspended in $0.5 \mathrm{~mL}$ of $1 \mathrm{x}$ PBS. The internalization of BTs was measured by flow cytometer (FACS Canto II, BD Biosciences, San Jose, CA, USA) using FACS Diva software (version 6.1.2, BD Biosciences) equipped with a $488 \mathrm{~nm}$ laser. Results were expressed as increase in SSC mean as compared to control. 
2.3.3. Cytotoxicity Assays. Cytotoxicity of BTs was determined by trypan blue dye exclusion assay and propidium iodide (PI) staining assay.

Trypan Blue Dye Exclusion Assay. Viability of A549 cells exposed to BTs was determined by trypan blue dye exclusion assay according to the method of Phillips [26]. In brief, cells were seeded in 24-well cell culture plates and after $22 \mathrm{~h}$ of seeding, cells were exposed to different concentrations of BTs for $6 \mathrm{~h}$ and $24 \mathrm{~h}$. After completion of exposure time, cells were harvested and centrifuged at $1200 \mathrm{rpm}$ for $10 \mathrm{~min}$. The cell pellet was washed with 1x PBS twice and finally the pellet was resuspended in $200 \mu \mathrm{L}$ of $1 \mathrm{x}$ PBS. Then, $10 \mu \mathrm{L}$ of sample was gently mixed with $10 \mu \mathrm{L}$ of trypan blue in an Eppendorf tube and incubated for $5 \mathrm{~min}$ at room temperature. This sample was loaded in a chamber slide and counted by using the cell counter (Countess Automated Cell Counter, Invitrogen, UK). The results were expressed as \% dead cells when compared with control.

Propidium Iodide (PI) Staining Assay. Propidium iodide (PI) dye was used for the flow cytometric assessment of live/dead cells. Briefly, cells were seeded in 12-well cell culture plates and exposed to different concentrations of BTs for $6 \mathrm{~h}$ and $24 \mathrm{~h}$. After completion of exposure, cells were harvested using $0.25 \%$ trypsin-EDTA and centrifuged at $1200 \mathrm{rpm}$ for $10 \mathrm{~min}$. Supernatant was discarded and the pellet was resuspended in $0.2 \mathrm{~mL}$ of $1 \mathrm{x}$ PBS containing PI having final concentration of $20 \mu \mathrm{g} / \mathrm{mL}$ and incubated for $10-15 \mathrm{~min}$ at $4^{\circ} \mathrm{C}$. After incubation, $0.2 \mathrm{~mL}$ of $1 \mathrm{x}$ PBS was again added and the samples were ready for acquisition using flow cytometer (FACS CantoII, BD Biosciences, San Jose, CA, USA) equipped with a $488 \mathrm{~nm}$ laser. Results were analysed using FACS Diva software (version 6.1.2, BD Biosciences) and expressed as percentage cell death when compared with control.

\subsubsection{Oxidative Stress Parameters}

(1) Measurement of Intracellular Reactive Oxygen Species (ROS). The level of intracellular ROS generation was estimated by the method of Wan et al. [27] and modified by Wilson et al. [28] using 2,7-dichlorofluorescein diacetate (DCFDA) dye. Cells were seeded in a 96-well black bottom plate and exposed to different concentrations of BTs for $1 \mathrm{~h}$, $3 \mathrm{~h}, 6 \mathrm{~h}$, and $24 \mathrm{~h}$ and cells without NPs were used as control and a set of experiments without cells were conducted in parallel. Following exposure, the cells were washed twice with $1 \mathrm{x}$ PBS and incubated with $20 \mu \mathrm{M}$ DCFDA dye prepared in 1x PBS for $30 \mathrm{~min}$ at $37^{\circ} \mathrm{C}$. After completion of incubation time, the reaction mixture was then replaced by $200 \mu \mathrm{L}$ of PBS and fluorescence intensity was measured in a SYNERGYHT multiwell plate reader, Bio-Tek (Winooski, USA), using KC4 software at excitation and emission wavelengths of $485 \mathrm{~nm}$ and $528 \mathrm{~nm}$, respectively, and results were expressed as percentage ROS generation as compared to control.

(2) Oxidative Stress Markers. Cells were cultured in T-75 $\mathrm{cm}^{2}$ culture flasks at a final density of $\sim 6 \times 10^{6}$ and exposed for $3 \mathrm{~h}$ and $6 \mathrm{~h}$. After exposure, the cells were washed twice with chilled 1x PBS and then scrapped on ice using 1x PBS. The cells were centrifuged at $1200 \mathrm{rpm}$ for $10 \mathrm{~min}$ and the pellet was resuspended in 1xPBS to obtain cell lysate. Protein content was measured by Bradford method [29] using BSA as standard.

Intracellular Glutathione (GSH) Estimation. GSH content was measured in lysate according to the method of Ellman [30] and expressed as $\mu \mathrm{mole} / \mathrm{mg}$ of protein.

Lipid Peroxidation (LPO) Assay. The rate of LPO was determined according to the method of Utley et al. [31] by estimating malondialdehyde (MDA) formed with 2-thiobarbituric acid (TBA).

\subsubsection{Mitochondrial Membrane Potential (MMP) Analysis} Using Lipophilic Fluorochrome. MMP was determined by using fluorescent, lipophilic cationic carbocyanine $5,5^{\prime}, 6,6^{\prime}$-tetrachloro-1, $1^{\prime} 3^{\prime} 3^{\prime}$-tetraethylbenzimidazolecarbocyanine iodide (JC-1) dye which exhibits dual fluorescence emission depending upon the membrane potential state of mitochondria. Exposed cells were harvested and washed with $1 \mathrm{x}$ PBS and then incubated with $10 \mu \mathrm{M} \mathrm{JC}-1$ for $15 \mathrm{~min}$ at $37^{\circ} \mathrm{C}$. After completion of incubation time, the stained cells were diluted with $1 \mathrm{x}$ PBS and were assayed using flow cytometer. The red and green fluorescence intensity was measured at an excitation wavelength of $485 \mathrm{~nm}$ and an emission wavelength of $520 \mathrm{~nm}$ and $600 \mathrm{~nm}$ for green and red fluorescence, respectively, using flow cytometry (FACS CantoII, BD Biosciences, San Jose, CA, USA) and results were analysed by using FACS Diva software (version 6.1.2, BD Biosciences).

2.3.6. Apoptosis (Annexin V/PI Double Staining). Apoptosis on exposure of BTs was measured by using Annexin VFITC apoptosis detection kit (BD Biosciences, San Jose, CA, USA) as per the manufacturer's protocol. Briefly, treated cells were harvested; cell pellet was washed with $1 \mathrm{x}$ PBS and resuspended in $100 \mu \mathrm{L}$ of $1 \mathrm{x}$ binding buffer $(10 \mathrm{mM}$ HEPES/NaOH, pH 7.5 containing $140 \mathrm{mM} \mathrm{NaCl}$ and $2.5 \mathrm{mM}$ $\mathrm{CaCl}_{2}$ ). $2 \mu \mathrm{L}$ of Annexin V-FITC and $2 \mu \mathrm{L}$ of PI were added to $100 \mu \mathrm{L}$ of cell suspension and incubated for $10 \mathrm{~min}$ in dark at $4^{\circ} \mathrm{C}$. After completion of incubation time, $400 \mu \mathrm{L}$ of $1 \mathrm{x}$ binding buffer was added and the cells were immediately analyzed by flow cytometry (FACS Canto II, BD Biosciences, San Jose, CA, USA) and results were analyzed by FACSDiva software, version 6.1.2 (BD Biosciences). The results were expressed as FITC negative and PI negative (viable normal cells), FITC positive and PI negative (early apoptotic), FITC positive and PI positive (late apoptotic), and FITC negative and PI positive (necrotic).

2.3.7. Assessment of Chromosomal Damage. Flow cytometric analysis of micronucleus formation $(\mathrm{MN})$ was done according to the method of Pandey et al. [32]. Cells were seeded in 6-well culture plates and exposed for $3 \mathrm{~h}$ and $6 \mathrm{~h}$. After the completion of exposure time, treatment was removed, cells were washed with incomplete medium, and 
TABLE 1: Characterisation of BTs by DLS.

\begin{tabular}{lcccc}
\hline S. Number & Medium & Hydrodynamic diameter & PdI & Zeta potential \\
\hline 1 & Culture medium (DMEM F-12 supplemented with 10\% FBS) & $179.7 \mathrm{~nm}$ & 0.354 & $12.9 \mathrm{mV}$ \\
\hline
\end{tabular}

fresh growth medium supplemented with 10\% FBS was added to each well and incubated till next division cycle. After incubation, cells were harvested and the pellet was resuspended in solution I (containing $10 \mathrm{mM} \mathrm{NaCl}, 3.4 \mathrm{mM}$ sodium citrate, $10 \mathrm{mg} / \mathrm{L}$ RNAse, $0.3 \mathrm{mg} / \mathrm{L}$ igepal, $25 \mathrm{mg} / \mathrm{L}$ $\mathrm{EtBr}$ ) and incubated for $45 \mathrm{~min}$ at room temperature in dark. Equal volume of solution II (1.5\% citric acid, $0.25 \mathrm{M}$ sucrose, $40 \mathrm{mg} / \mathrm{L} \mathrm{EtBr}$ ) was added with vortexing for 2-3 seconds and samples were placed at $4^{\circ} \mathrm{C}$, ready for acquisition using flow cytometer (FACS CantoII, BD Biosciences, San Jose, CA, USA) equipped with $488 \mathrm{~nm}$ laser and analysed by FACS Diva software (version 6.1.2, BD Biosciences). Results were expressed as percentage micronucleus formed per nucleus.

2.3.8. Assessment of Cell Cycle Progression. Effect of BTs on cell cycle progression was determined by using flow cytometer. Briefly, the treated cells were harvested and fixed in $70 \%$ ethanol for $30 \mathrm{~min}$ at $4^{\circ} \mathrm{C}$ and then lysed with $0.2 \%$ triton X-100 for $30 \mathrm{~min}$ at $4^{\circ} \mathrm{C}$. After lysis, cells were incubated for $30 \mathrm{~min}$ in dark at $37^{\circ} \mathrm{C}$ in RNase $\mathrm{A}(10 \mathrm{mg} / \mathrm{mL})$ and finally stained with PI $(1 \mathrm{mg} / \mathrm{mL})$ for $60 \mathrm{~min}$ at $4^{\circ} \mathrm{C}$. Then, the flow cytometric analysis was performed using BD FACS Canto II flow cytometer equipped with FACS Diva software (version 6.1.2, BD Biosciences) and results were expressed in percentage cell population in different phases of cell cycle.

2.4. Statistical Analysis. All assays were done in three independent sets of experiments and results were expressed as mean \pm SEM. Data of treated cells were compared with their respective controls and were analysed using one way analysis of variance (ANOVA) with Dunnett post hoc test to determine significance. In all cases $P<0.05$ was considered statistically significant.

\section{Results}

3.1. Characterisation of Bucky Tubes. BTs were first analysed by TEM to assess the particle morphology and size. TEM analysis shows that the particles were tubular in shape with an average (bundle diameter) size of $\sim 37.2 \mathrm{~nm}$ at scale bar of $100 \mathrm{~nm}$ (Figure 1(a)).

Further, the mean hydrodynamic diameter and zeta potential of BTs in cell culture medium DMEM F-12 supplemented with 10\% FBS were estimated using DLS and found to be in range of $179.7 \mathrm{~nm}$ and $12.9 \mathrm{mV}$, respectively, with polydispersity index (PdI) 0.354 (Table 1).

FT-IR spectra of BTs exhibited the presence of characteristic peaks at $2600 \mathrm{~cm}^{-1}, 2325 \mathrm{~cm}^{-1}, 1111 \mathrm{~cm}^{-1}$, and $465 \mathrm{~cm}^{-1}$ corresponding to the two-dimensional carbon nanostructures (Figure 1(b)).

$\mathrm{X}$-ray diffraction pattern of BTs taken in the $2 \theta$ range of 5$80^{\circ}$ revealed the major diffraction peaks at $25.6^{\circ}, 42.4^{\circ}, 53.5^{\circ}$, and $77.2^{\circ}$, which are discussed in detail later (Figure 1(c)).
3.2. Intracellular Internalization of Carbon Nanoparticles. The cellular uptake of BTs was assessed by flow cytometry. The change in side scattering (SSC) mean and forward scattering (FSC) mean represents the relative change in granularity and size of the cell, respectively. There was an increase in SSC mean with the increase in concentration at $1,10,25,50$, and $100 \mu \mathrm{g} / \mathrm{mL}$ after $6 \mathrm{~h}$ and $24 \mathrm{~h}$ exposure as represented in Figure 2. The percentage increase in SSC mean of cells treated with BTs was statistically significant $(P<0.01, P<0.001)$ at $50 \mu \mathrm{g} / \mathrm{mL}$ and $100 \mu \mathrm{g} / \mathrm{mL}$ after $24 \mathrm{~h}$ exposure.

3.3. Cytotoxicity Assessment. For determining cytotoxicity by trypan blue dye exclusion assay and PI staining assay, cells were exposed to varying concentration $(1 \mu \mathrm{g} / \mathrm{mL}-100 \mu \mathrm{g} / \mathrm{mL})$ of BTs for $6 \mathrm{~h}$ and $24 \mathrm{~h}$. It was revealed from both assays that there was a concentration and time dependent increase in cell death as compared to control. There was statistically significant $(P<0.05, P<0.001)$ increase in cell death from $1.30 \%$ to $4.70 \%$ and $5.70 \%$ after $6 \mathrm{~h}$ exposure which increased from $2.30 \%$ to $8.70 \%$ and $10.7 \%$ after 24 h exposure at $50 \mu \mathrm{g} / \mathrm{mL}$ and $100 \mu \mathrm{g} / \mathrm{mL}$ concentrations, respectively, as observed from trypan blue dye exclusion assay (Figure 3(a)). PI staining method showed the similar trend, that is, $3.00 \%$, $3.43 \%$ at $6 \mathrm{~h}$ and $5.30 \%, 9.33 \%$ at $24 \mathrm{~h}$ exposure at $50 \mu \mathrm{g} / \mathrm{mL}$ and $100 \mu \mathrm{g} / \mathrm{mL}$ concentrations, respectively, when compared with respective controls (1.80\% and 2.23\%) (Figure 3(b)).

3.4. Analysis of Oxidative Stress Parameters (Intracellular ROS, GSH, and LPO). A549 cells were loaded with $2^{\prime}, 7^{\prime}$ dichlorodihydrofluorescein diacetate and it was observed that BTs induced ROS generation in both time and concentration dependent manner which was revealed from increase in DCF fluorescence. The fluorescence intensity increased from $101.71 \%, 106.37 \%, 119.21 \%$, and $142.49 \%$ after $1 \mathrm{~h}$ and $109.77 \%, 130.12 \%, 144.55 \%$, and $202.43 \%$ after $3 \mathrm{~h}$ exposure of BTs as compared to control. The fluorescence intensity was decreased from $95.7 \%, 120.98 \%, 137.11 \%$, and $195.23 \%$ after $6 \mathrm{~h}$ and $89.58 \%, 109.57 \%, 100.29 \%$, and $126.32 \%$ after $24 \mathrm{~h}$ exposure of BTs at concentrations $(10-100 \mu \mathrm{g} / \mathrm{mL})$ as compared to control (Figure 4(a)). A statistically significant reduction $(P<0.05, P<0.001)$ in cellular GSH content (Figure 4(b)) with increase in lipid peroxidation (Figure 4(c)) was observed after $3 \mathrm{~h}$ and $6 \mathrm{~h}$ exposure to BTs in A549 when compared with respective control.

3.5. Detection of Changes in Mitochondrial Membrane Potential. Cells treated with BTs showed a statistically significant $(P<0.001)$ mitochondrial membrane depolarization which was detected by JC-1 dye using flow cytometer. Normal healthy (polarized) cells showed higher levels of fluorescence emission measured in red channel while cells in which dye does not accumulate in mitochondria showed depolarized membrane having more fluorescence in green channel. Our data represents $5.03 \%$ and $11.53 \%$ depolarized cells at 


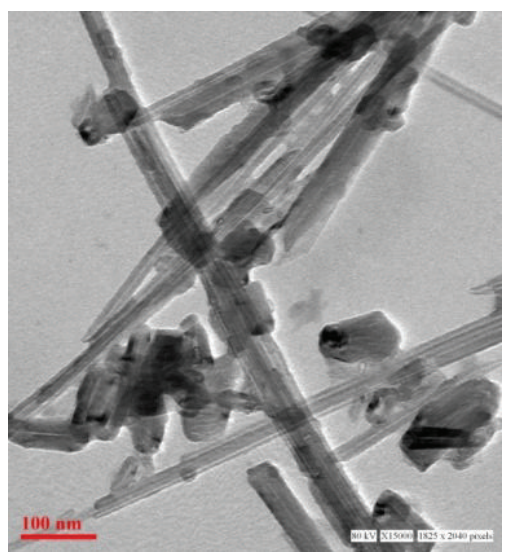

(a)

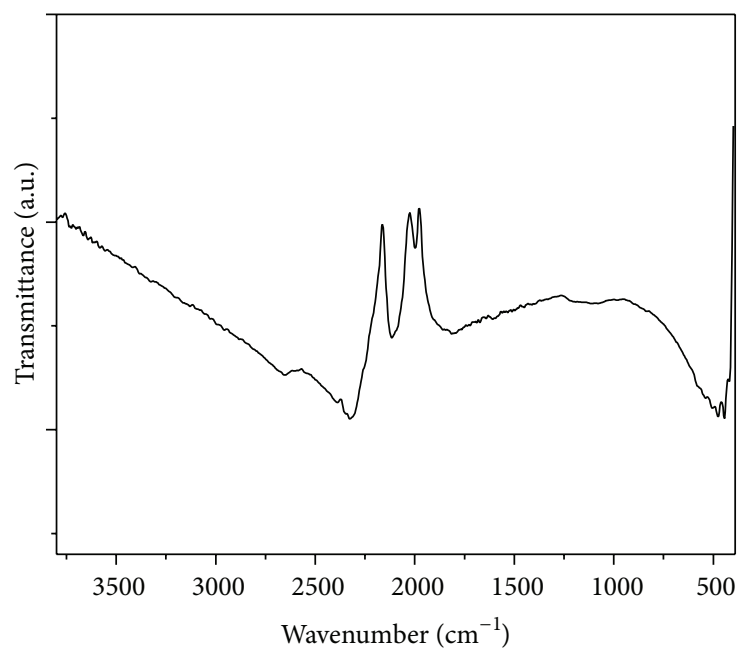

(b)

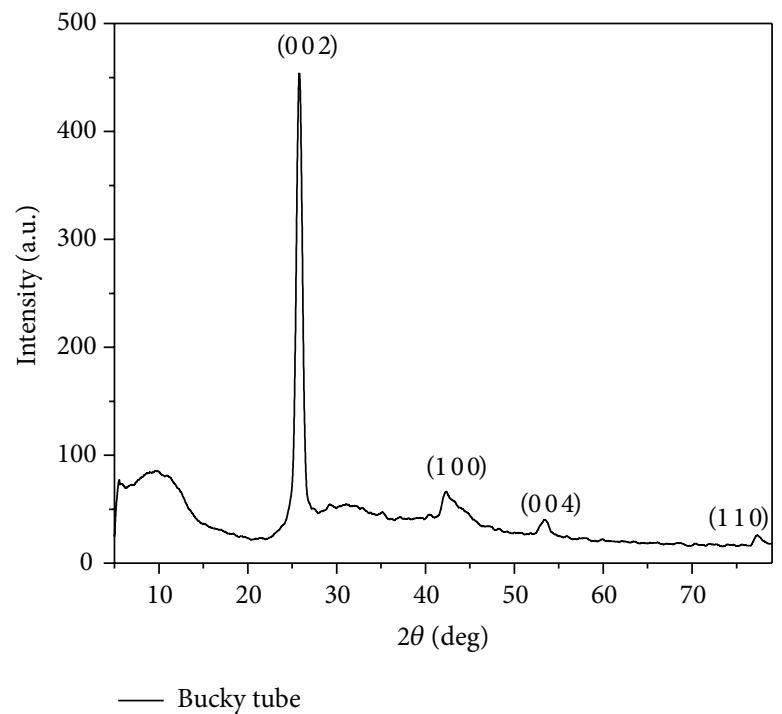

(c)

FIGURE 1: Characterization of BTs: (a) TEM photomicrograph: TEM analysis revealed that BTs were tubular/rod shaped having $~ 37.2 \mathrm{~nm}$ average (bundle) size at scale bar of $100 \mathrm{~nm}$. (b) FTIR analysis revealed the presence of characteristic peaks corresponding to two-dimensional carbon nanostructures. (c) XRD pattern of BTs.

$50 \mu \mathrm{g} / \mathrm{mL}$ and $100 \mu \mathrm{g} / \mathrm{mL}$ when compared with control cells $(0.33 \%)$ (Figures 5(a) and 5(b)).

3.6. Apoptosis (Annexin V/PI Double Staining). The cell population of interest was gated on the basis of untreated control stained cells. These were divided into four quadrants and were analysed as FITC negative and PI negative (viable normal cells), FITC positive and PI negative (early apoptotic), FITC positive and PI positive (late apoptotic), and FITC negative and PI positive (necrotic). It was observed that there was increase in percentage of $\mathrm{FITC}^{-}$and $\mathrm{PI}^{+}$population and decrease in $\mathrm{FITC}^{+} \mathrm{PI}^{+}$and $\mathrm{FITC}^{+} \mathrm{PI}^{-}$population with increasing concentration which suggest that at lower concentration BTs cause apoptosis in A549 cells and at higher concentration cause necrosis (Figures 6(a) and 6(b)).
3.7. Chromosomal Damage and Progression of Cell Cycle. A statistically significant $(P<0.05)$ induction of $\mathrm{MN}$ formation was observed in A549 after $3 \mathrm{~h}$ and $6 \mathrm{~h}$ exposure to BTs from $12.9 \%$ and $23.0 \%$, respectively, at $100 \mu \mathrm{g} / \mathrm{mL}$ by flow $\mathrm{MN}$ with respect to control $2.7 \%$ (Figure 7).

Flow cytometric analysis of cell cycle of A549 cells exposed to BTs for $24 \mathrm{~h}$ revealed that there was a significant concentration dependent increase in cells present in sub-G1 phase $(4.4 \%, 2.8 \%, 3.7 \%, 5.3 \%$, and $8.3 \%)$ in comparison to control (2.6\%) while there is no significant change in percentage of cells in G1, S, and G2/M phase of cell cycle which revealed that there was increase in apoptotic cell population (Figures 8(a), 8(b), and $8(\mathrm{c})$ ). 


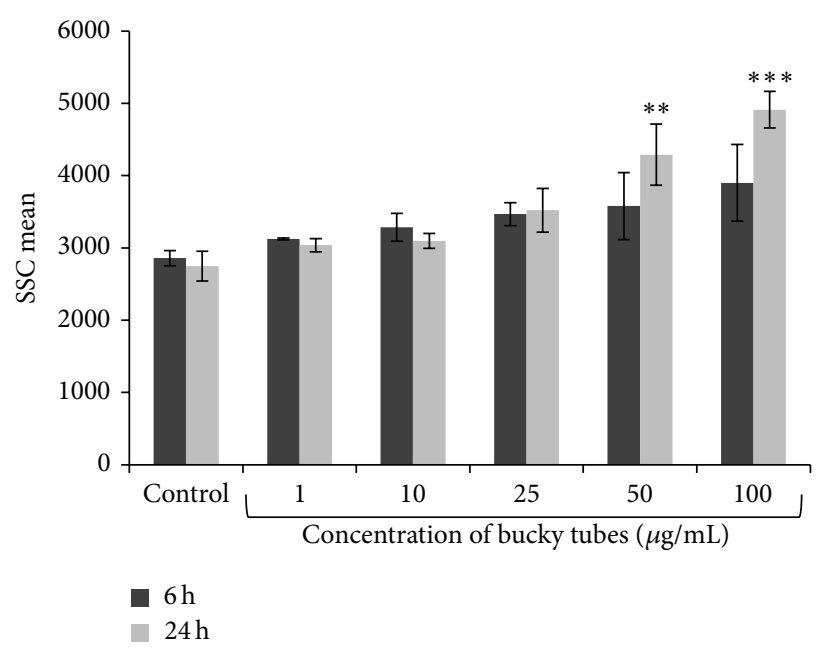

FIGURE 2: Internalization of BTs in A549 cells after $6 \mathrm{~h}$ and $24 \mathrm{~h}$ exposure. Increase in SSC mean correlates with the increased granularity of cells which was used as a marker for internalization of NPs. Values represent mean \pm SEM of three independent experiments. $\left({ }^{* *} P<0.01\right.$, ${ }^{* * *} P<0.001$ when compared to control).

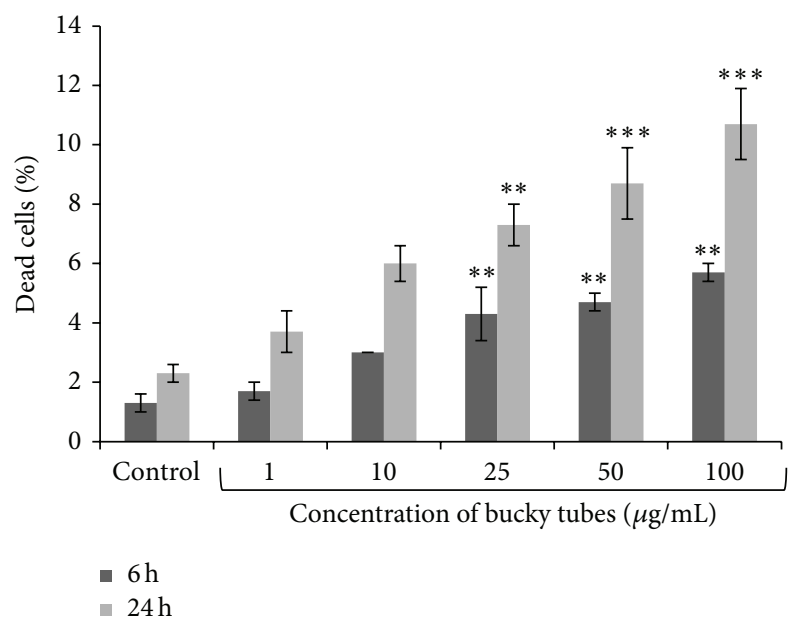

(a)

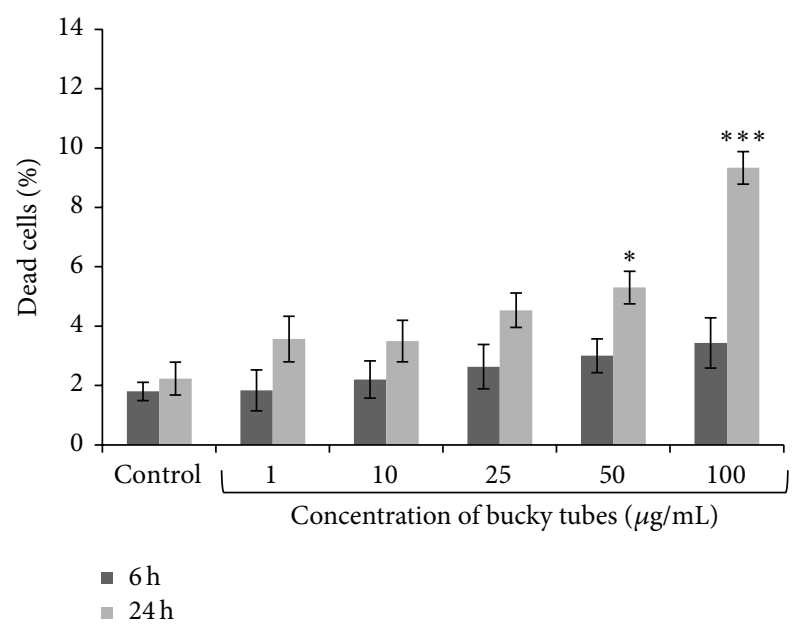

(b)

FIgURE 3: Cytotoxic effect of BTs NPs in A549 cells by (a) trypan blue dye exclusion assay using automatic cell counter and (b) propidium iodide (PI) uptake method in which cells were stained with PI and analysed by flow cytometer after $6 \mathrm{~h}$ and $24 \mathrm{~h}$ exposure. Results were expressed as the percentage cell death after exposure of BT relative to control cells and were represented as mean \pm SEM of three independent experiments. $\left({ }^{*} P<0.05,{ }^{* *} P<0.01\right.$, and ${ }^{* * *} P<0.001$ when compared to control).

\section{Discussion}

MWCNTs are produced in huge amount and exponentially applied in almost all sectors. These increasing applications necessitate the evaluation of risk of MWCNTs exposure and their adverse health effects.

Therefore, present study was designed to evaluate the toxicity of BTs (type of MWCNTs) and add to the present knowledge by concluding that BTs get internalized and cause cellular toxicity. It causes oxidative stress by generation of intracellular ROS which induce lipid peroxidation that leads to imbalance in level of antioxidants. It has been also observed that BTs exposure causes mitochondrial dysfunctioning, chromosomal damage, and cell cycle arrest for which oxidative stress may be one of the possible reasons.
Prior to investigating the in vitro toxicity, characterization of experimental nanoparticles is essential as the shape, size, particle dispersity, and charge on its surface primarily affect the biological responses [33]. Hence, first of all we examined BTs by electron microscopy (TEM) which is the most widely used technique and directly measures the particle size and morphology. Size of particles observed by TEM was $\sim 37.2 \mathrm{~nm}$ (bundle diameter) having tubular structure of the diameter ranging from 5 to $10 \mathrm{~nm}$.

Another method used was DLS which characterize the particle in the cell culture medium which was used for treatment of BTs to A549 so as to characterise the particle by simulating the culture conditions. The mean hydrodynamic diameter and zeta potential of BTs in culture medium 


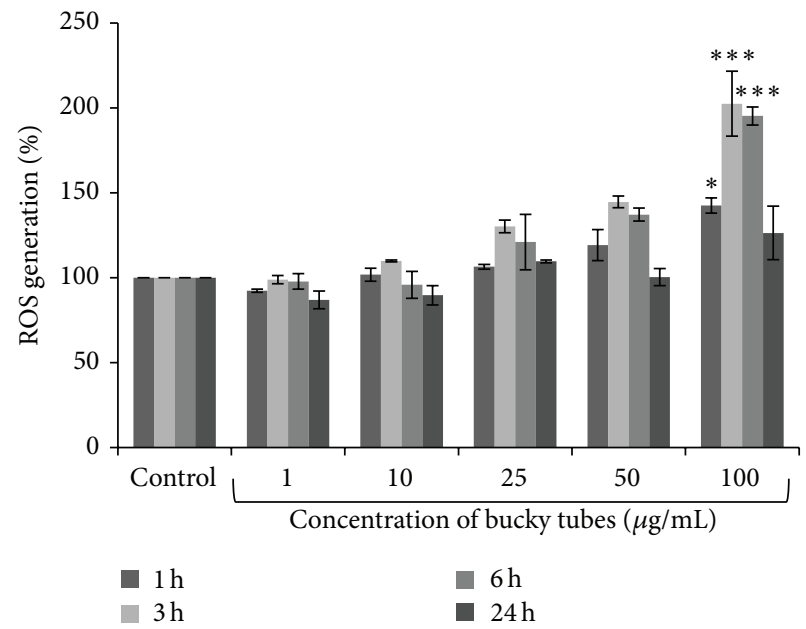

(a)

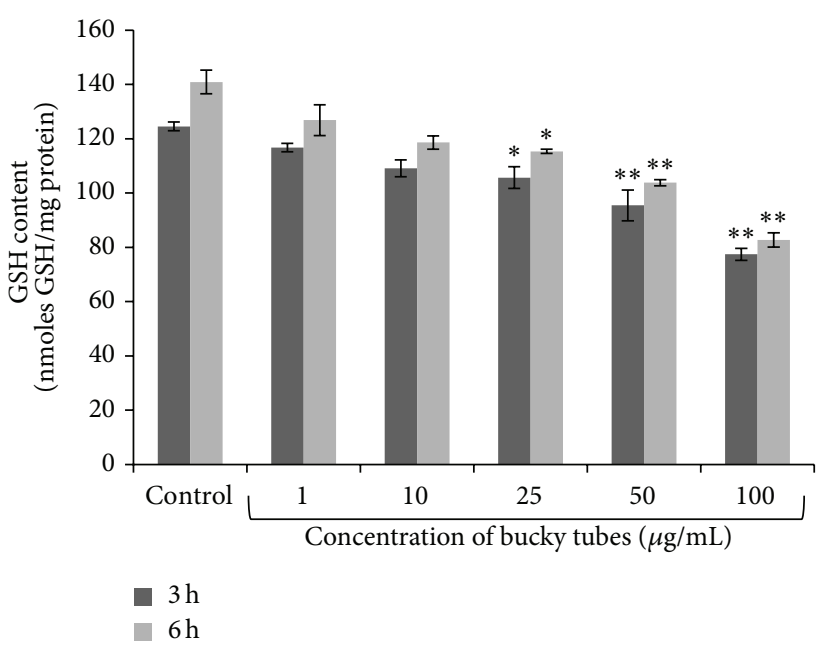

(b)

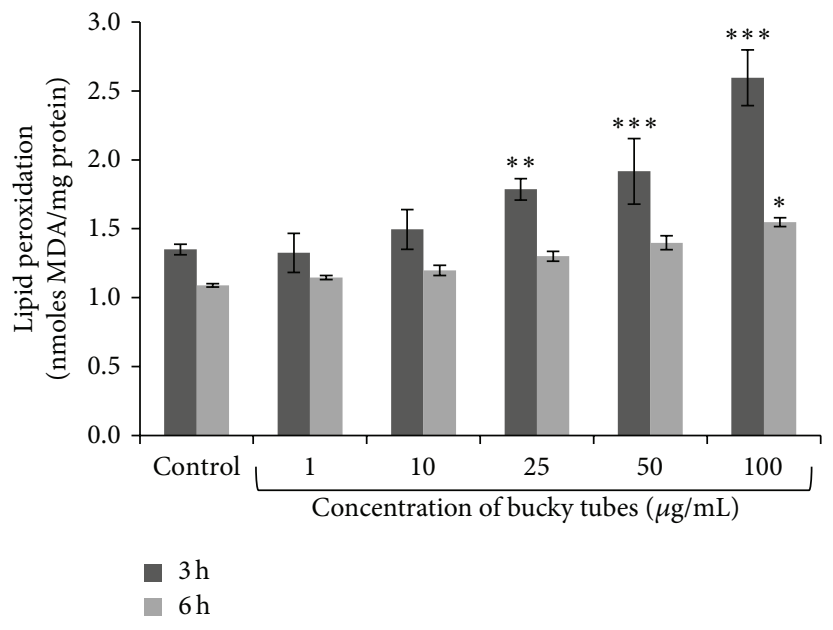

(c)

FIGURE 4: Effect of BTs NPs on (a) induction of intracellular reactive oxygen species (ROS), (b) cellular level of glutathione (GSH), and (c) lipid peroxidation (LPO) in A549 cells. The \% ROS generation of the control cells was considered 100\% and fluorescence intensity was measured by microplate reader while glutathione level and lipid peroxidation were measured spectrophotometrically. Data represents mean \pm SEM of three independent experiments. $\left({ }^{*} P<0.05,{ }^{* *} P<0.01\right.$, and ${ }^{* * *} P<0.001$ when compared to control).

obtained from DLS were in the range of $179.7 \mathrm{~nm}$ and $12.9 \mathrm{mV}$, respectively, at physiological $\mathrm{pH}$ which was more than the size reported $(7-12 \mathrm{~nm})$ by its commercial supplier (SigmaAldrich). The reason behind the vast difference in particle size may be that DLS characterise the particle considering it spherical in shape which is not in the case of BTs as these are tubular in structure. Moreover, difference in particle size may be due to agglomeration which is influenced by intrinsic and extrinsic factors [33].

A FT-IR spectrum of BTs illustrates the presence of characteristic peaks related to 2-dimensional carbon nanostructures. Stretching at around $2600 \mathrm{~cm}^{-1}$ has been assigned to $\mathrm{C}-\mathrm{O}$ stretching that may correspond to the presence of $-\mathrm{COOH}$ groups. Several minor peaks appeared due to amorphous content, C-H stretching vibrations $\left(\sim 2325 \mathrm{~cm}^{-1}\right.$, $\sim 1111 \mathrm{~cm}^{-1}$, and $\sim 465 \mathrm{~cm}^{-1}$ ), and so forth; stretching at $\sim 2100 \mathrm{~cm}^{-1}$ is due to the interference of $\mathrm{CO}_{2}$ during the course of the spectral measurements.

X-ray diffraction pattern of BTs showed the graphitic structure with interlayer spacing of $0.33 \mathrm{~nm}$ corresponding to the $\mathrm{d}_{002}$ reflection at $25.6^{\circ}$. Peaks at $42.4^{\circ}, 53.5^{\circ}$, and $77.2^{\circ}$ were attributed to the diffraction of (1 00$)$, ( 004$)$, and (110) planes, respectively, which suggested the BTs structural resemblance to the multiwalled carbon nanotubes.

To explore the toxicity potential of BTs, it is necessary to evaluate the internalization of BTs which can be correlated with varying biological responses. The cellular uptake of nanoparticles was considered as a primary method of screening of nanotoxicity by flow cytometer [25] and therefore, BTs were examined by measuring the relative change in cell granularity (SSC). Our preliminary study on A549 cells demonstrated a significant increase in SSC 


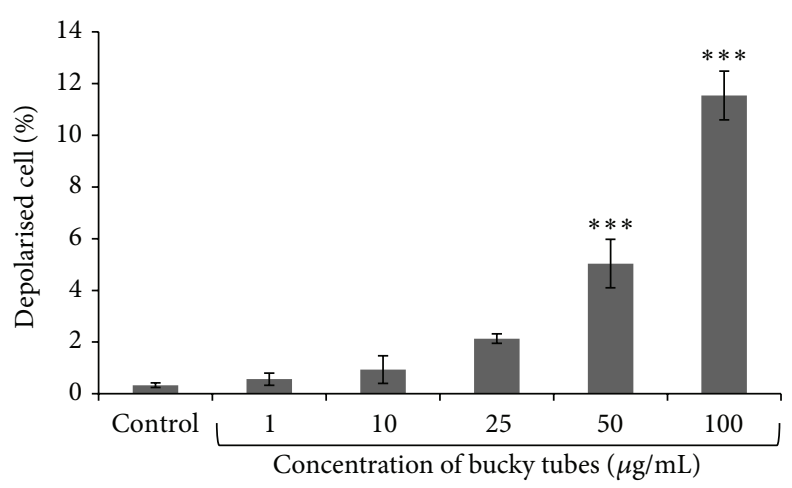

(a)
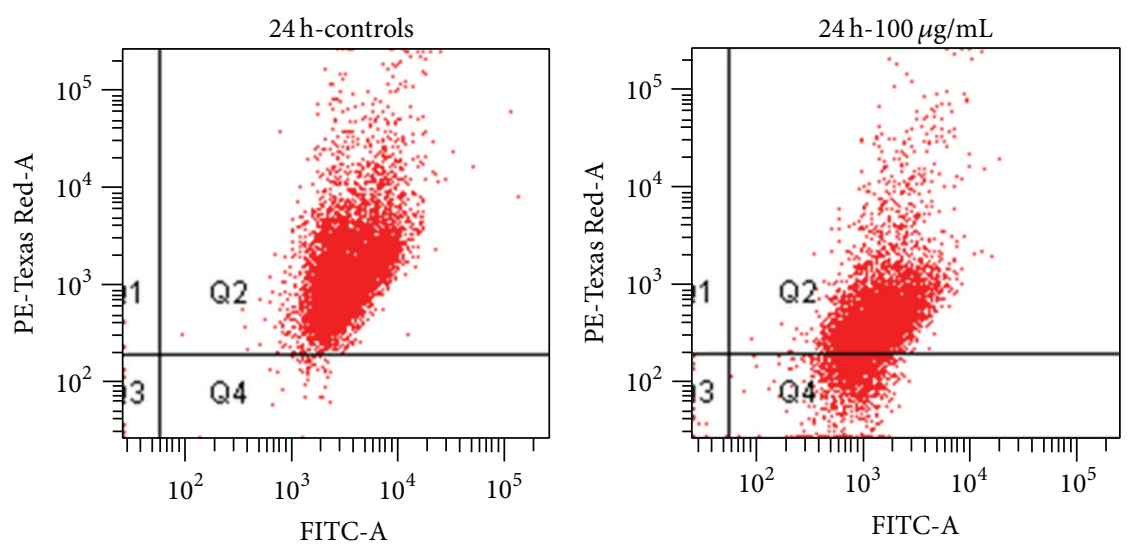

(b)

FIGURE 5: Flow cytometric detection of change in mitochondrial membrane potential (MMP) in A549 cells exposed to BTs using JC-1 dye. (a) Representative bar graph of three independent experiments analysed. (b) Representative dot plots. Data represent mean \pm SEM of three experiments. $\left({ }^{* * *} P<0.001\right.$ when compared to control).

mean (marker of granularity) in a time and concentration dependent manner which suggests that there was uptake of BTs in treated cells when compared with untreated cells. There were several reports which suggest that increase in SSC mean is the indicator of increase in cellular granularity on the internalization of NPs [34-36].

After internalization studies, effect of BTs on cellular viability was examined by trypan blue dye exclusion assay and PI assay. It was found that BTs exposure causes a statistically significant decrease in cell viability in lung alveolar cells in both assays at higher concentration at different time points. Several groups have reported that, after internalization, NPs interact with cellular components that induce alteration in cellular/functional responses which ultimately leads to cell death $[34,37]$.

Further, to investigate the cause of cytotoxicity, we tried to identify the generation of free radicals which are considered to be the primary cause of toxicity due to exposure of NPs $[35,38-40]$. On analysing the effects of BTs exposure to A549 at different time points, we found that these induced intracellular ROS generation up to $3 \mathrm{~h}$ and decreased further. This decrease in ROS after $3 \mathrm{~h}$ may be due to the decrease in viable cells or ROS generated may be stabilized after certain duration.
It is documented that oxidative stress occurs in a cell or tissue when the concentration of ROS generated exceeds the antioxidant capability of that cell [41-43]. Therefore, we tried to determine the level of one of the major endogenous antioxidants and free radical scavengers, that is, glutathione, which is mostly $(90 \%)$ present in reduced form in healthy cells and in the present study, there was decrease in level of GSH in treated cells as compared to untreated one which may be possibly due to elevated level of intracellular free radicals.

In addition, overproduction of ROS may result in damage to critical biomolecules including cellular fatty acids which are readily oxidized to produce lipid peroxyl radicals and lipid hydroperoxides. Lipid peroxyl radicals are subsequently propagated into malondialdehyde (MDA) which is the major carbonyl produced during LPO and potent mutagen and carcinogenic compound. We explored the level of cellular fatty acids and found that there was increase in level of LPO with increasing concentration which represents the increased toxicity due to free radical generation.

Based on a study on wide body of literature it is seen that severe oxidative stress can cause instability in mitochondrial membrane potential, DNA damage, and/or cell death and even moderate oxidation can trigger apoptosis, while more intense stresses may cause necrosis $[44,45]$. In 


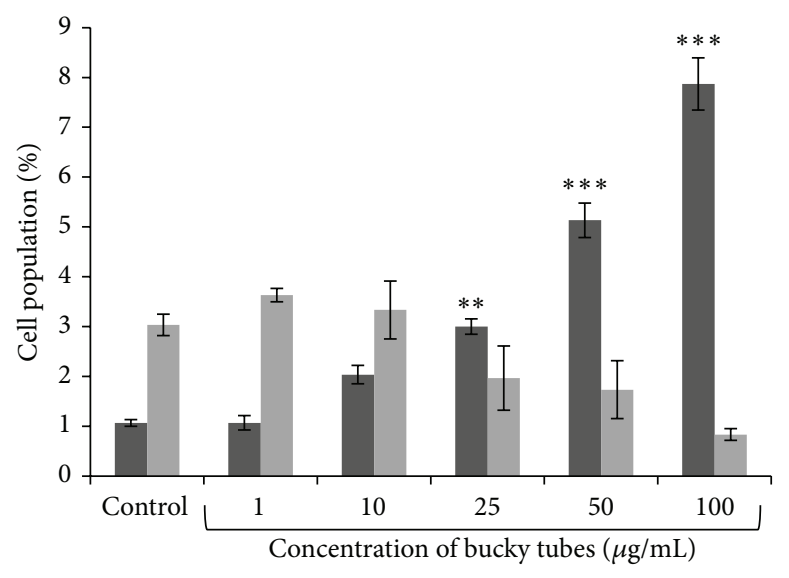

- Necrotic

- Apoptotic

(a)
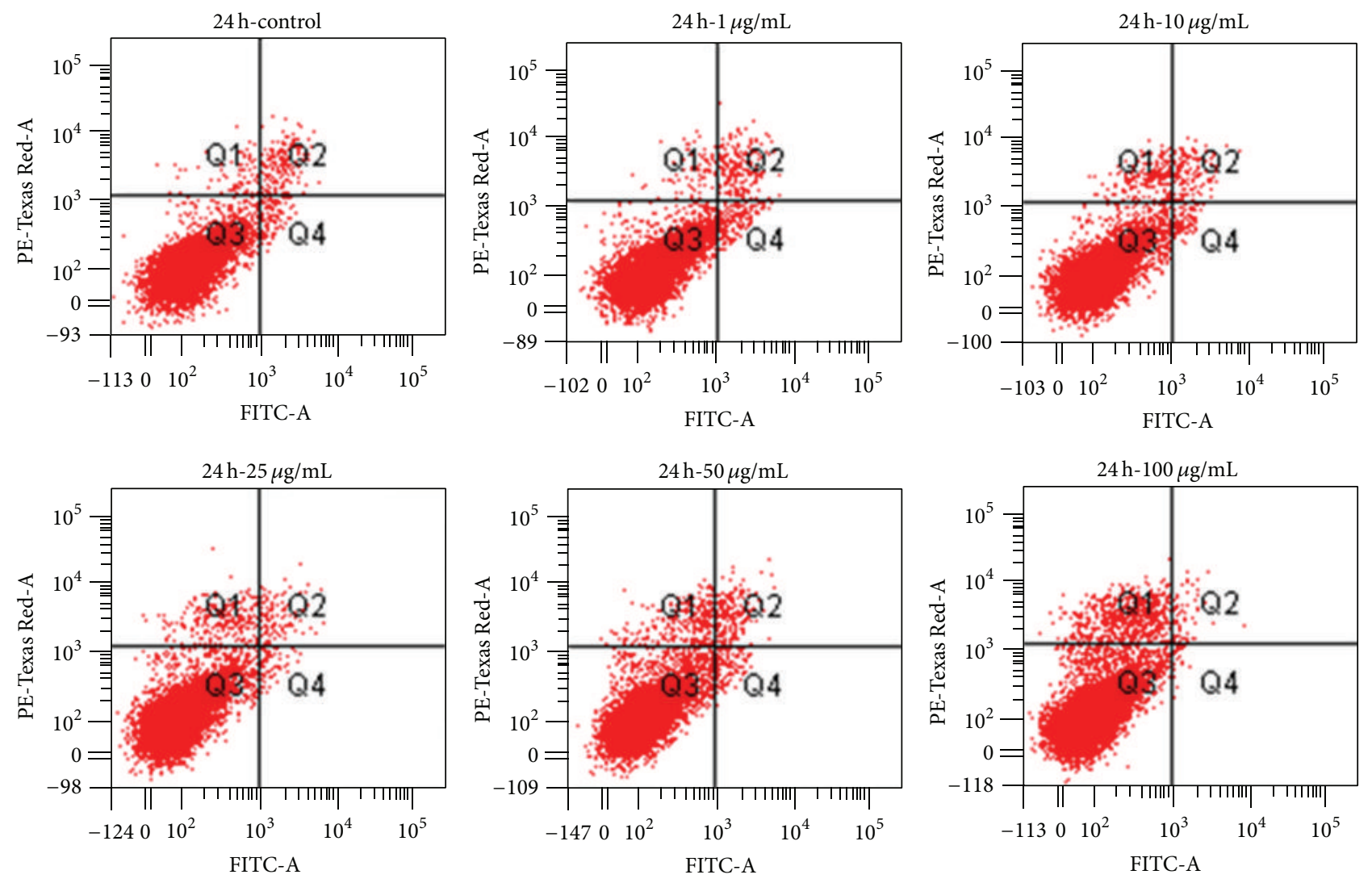

(b)

FIgURE 6: BTs induced cell death in A549 cells analysed by flow cytometry. Data represent mean \pm SEM of three experiments. (a) Representative bar graph. (b) Dot plots. $\left({ }^{* *} P<0.01,{ }^{* * *} P<0.001\right.$ when compared to control).

the present study, MMP was evaluated by JC-1 dye which is positively charged, having dual fluorescence spectra and gets accumulated in the electronegative leaflet (interior) of polarised mitochondria as aggregates. Change in redox potential causes depolarization of mitochondrial membrane allowing mitochondrial permeability transition pores to pass
JC-1 aggregates from interior to outer environment and reside there as monomers. Our results indicated that there was a statistically significant increase in JC-1 monomers at $50 \mu \mathrm{g} / \mathrm{mL}$ and $100 \mu \mathrm{g} / \mathrm{mL}$ which was correlated with the loss in mitochondrial membrane potential. Our results were in accordance with previous reports which showed that the 


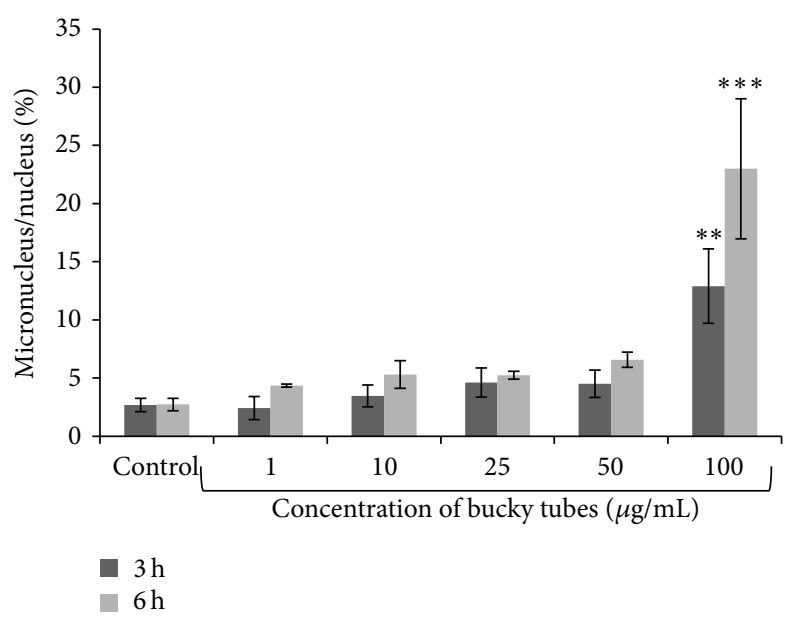

FIGURE 7: Flow cytometric detection of chromosomal damage by micronucleus formation after $3 \mathrm{~h}$ and $6 \mathrm{~h}$ of exposure. Data represent mean \pm SEM of three experiments. $\left({ }^{* *} P<0.01,{ }^{* * *} P<0.001\right.$ when compared to control).

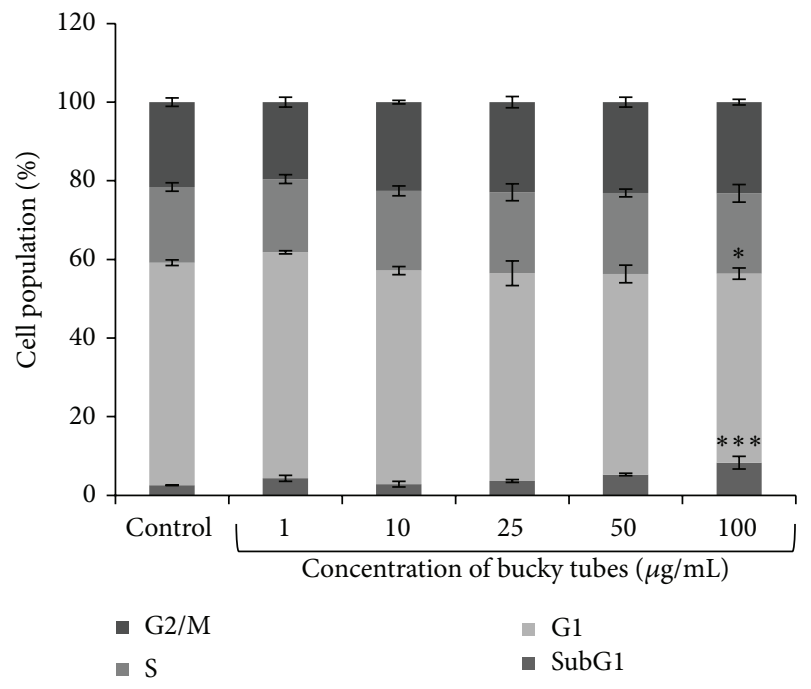

(a)

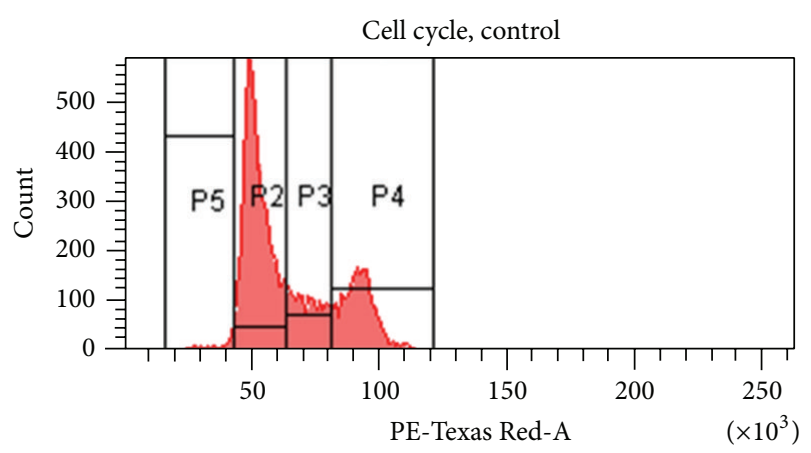

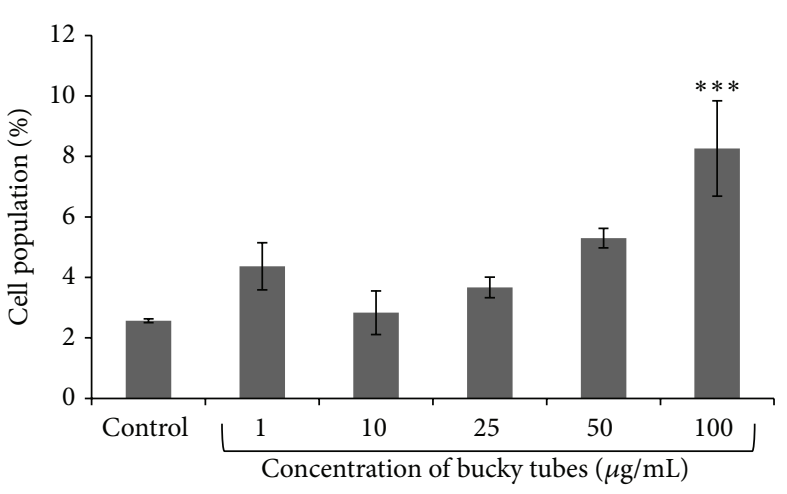

(b)

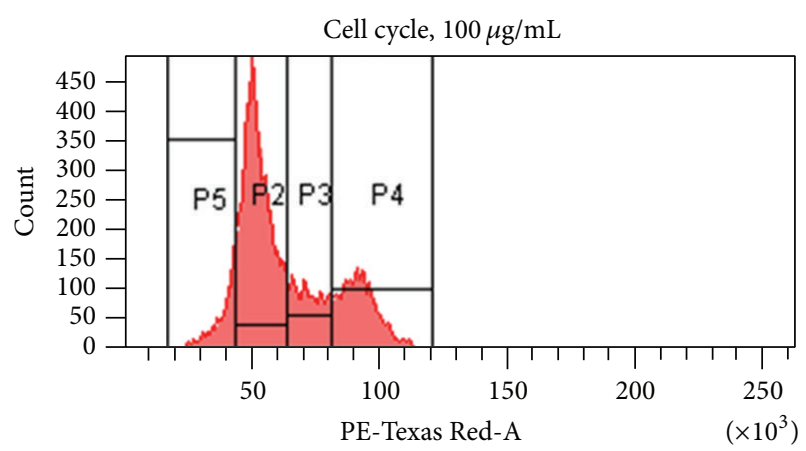

(c)

FIGURE 8: Flow cytometric analysis of cell cycle of A549 cells exposed to BTs for $24 \mathrm{~h}$. (a) Bar graph representing cell population in different phases of cell cycle and (b) representing \% cell population in sub-G1 phase which ultimately represents apoptotic population and (c) representative histograms. $\left({ }^{*} P<0.05,{ }^{* * *} P<0.001\right.$ when compared to control). 
exposure of nanoparticles causes toxicity and alteration in mitochondrial functioning which may be due to loss in membrane potential $[37,46,47]$.

Moreover, it can be said that disruption of mitochondrial activity is the distinctive feature in cell death and in accordance with this we assessed cell fate by Annexin V/PI double staining and found that at lower concentration BTs cause apoptosis in A549 cells and at higher concentration causes necrosis. It can be concluded that BTs were mild toxic towards A549 and lead to cell death. Some of the previous reports have shown that mitochondrial dysfunction is activated with accidental cell death (necrosis) or programmed cell death $[48,49]$.

Another important outcome of these deleterious reactive radicals is that they can diffuse through membranes and may also interact with cellular DNA and nitrogen bases by forming adducts resulting in a loss of cellular homeostasis [50]. It causes chromosomal damage through micronucleus formation which arises when acentric chromosomal fragments and/or whole chromosome are excluded from the main nucleus at the telophase of cell division. Hence, micronucleus assay was used for detecting the genotoxic potential of those agents that induce chromosomal breakage and instability in spindle formation [51]. We evaluated the genotoxic potential (micronucleus formation) of BTs in A549 by flow cytometric method and observed that BTs exposure causes the increase in number of $\mathrm{MN}$ formed with the increase in concentration as analysed by flow cytometer suggesting chromosomal damage.

Further, in response to DNA damage, progression of cell cycle was assessed by PI staining flow cytometrically and it was observed that there was statistically significant increase in apoptotic cell population in exposed cells at $100 \mu \mathrm{g} / \mathrm{mL}$ (indicated by Sub-G1 phase) as compared to control.

\section{Conclusion}

Present study demonstrated that BTs get internalized intracellularly to human lung alveolar cells and cause cell death with increasing concentrations and time points which was observed by flow cytometer. Exposure of these nanoparticles causes increased ROS production and lipid peroxidation with concomitant depletion in glutathione level which confirms the induction of oxidative stress which ultimately triggers loss in MMP at $100 \mu \mathrm{g} / \mathrm{mL}$ concentration. Along with this, BTs cause oxidative stress which may lead to chromosomal damage causing micronucleus formation and cell death as revealed from Annexin V/PI double staining and cell cycle analysis. Overall study determines that these BT NPs were mild toxic towards human lung alveolar cell lines showing statistically significance but seems to be less significant biologically. So, these CNMs can be considered to be safe in some specific cases.

\section{Conflict of Interests}

The authors declare that there is no conflict of interests.

\section{Acknowledgments}

The authors gratefully acknowledge the funding from CSIR, New Delhi, for EMPOWER scheme (OLP-06) and Network project NanoSHE (BSC0112). Authors are thankful to Dr. L. K. S. Chauhan for his help in TEM imaging.

\section{References}

[1] X. Luo, A. Morrin, A. J. Killard, and M. R. Smyth, "Application of nanoparticles in electrochemical sensors and biosensors," Electroanalysis, vol. 18, no. 4, pp. 319-326, 2006.

[2] E. C. Wang and A. Z. Wang, "Nanoparticles and their applications in cell and molecular biology," Integrative Biology, vol. 6, no. 1, pp. 9-26, 2014.

[3] N. Vigneshwaran, A. A. Kathe, P. V. Varadarajan, R. P. Nachane, and R. H. Balasubramanya, "Functional finishing of cotton fabrics using silver nanoparticles," Journal of Nanoscience and Nanotechnology, vol. 7, no. 6, pp. 1893-1897, 2007.

[4] B. S. Harrison and A. Atala, "Carbon nanotube applications for tissue engineering," Biomaterials, vol. 28, no. 2, pp. 344-353, 2007.

[5] Y. Zhang, Y. Bai, and B. Yan, "Functionalized carbon nanotubes for potential medicinal applications," Drug Discovery Today, vol. 15, no. 11-12, pp. 428-435, 2010.

[6] Z. Liu, X. Sun, N. Nakayama-Ratchford, and H. Dai, "Supramolecular chemistry on water-soluble carbon nanotubes for drug loading and delivery," ACS Nano, vol. 1, no. 1, pp. 50-56, 2007.

[7] A. Star, J.-C. P. Gabriel, K. Bradley, and G. Grüner, "Electronic detection of specific protein binding using nanotube FET devices," Nano Letters, vol. 3, no. 4, pp. 459-463, 2003.

[8] X. Chen, A. Kis, A. Zettl, and C. R. Bertozzi, "A cell nanoinjector based on carbon nanotubes," Proceedings of the National Academy of Sciences of the United States of America, vol. 104, no. 20, pp. 8218-8222, 2007.

[9] K. Donaldson, R. Aitken, L. Tran et al., "Carbon nanotubes: a review of their properties in relation to pulmonary toxicology and workplace safety," Toxicological Sciences, vol. 92, no. 1, pp. 5-22, 2006.

[10] E. A. Eisen, S. Costello, J. Chevrier, and S. Picciotto, "Epidemiologic challenges for studies of occupational exposure to engineered nanoparticles; a commentary," Journal of Occupational and Environmental Medicine, vol. 53, no. 6, pp. S57-S61, 2011.

[11] C.-W. Lam, J. T. James, R. McCluskey, S. Arepalli, and R. L. Hunter, "A review of carbon nanotube toxicity and assessment of potential occupational and environmental health risks," Critical Reviews in Toxicology, vol. 36, no. 3, pp. 189-217, 2006.

[12] A. Helland, P. Wick, A. Koehler, K. Schmid, and C. Som, "Reviewing the environmental and human health knowledge base of carbon nanotubes," Ciencia e Saude Coletiva, vol. 13, no. 2, pp. 441-452, 2008.

[13] J. Cheng and S. H. Cheng, "Influence of carbon nanotube length on toxicity to zebrafish embryos," International Journal of Nanomedicine, vol. 7, pp. 3731-3739, 2012.

[14] J. N. Mwangi, N. Wang, C. G. Ingersoll et al., "Toxicity of carbon nanotubes to freshwater aquatic invertebrates," Environmental Toxicology and Chemistry, vol. 31, no. 8, pp. 1823-1830, 2012.

[15] J. C. Bonner, "Nanoparticles as a potential cause of pleural and interstitial lung disease," Proceedings of the American Thoracic Society, vol. 7, no. 2, pp. 138-141, 2010. 
[16] S. Hirano, S. Kanno, and A. Furuyama, "Multi-walled carbon nanotubes injure the plasma membrane of macrophages," Toxicology and Applied Pharmacology, vol. 232, no. 2, pp. 244-251, 2008.

[17] Y.-G. Han, J. Xu, Z.-G. Li, G.-G. Ren, and Z. Yang, "In vitro toxicity of multi-walled carbon nanotubes in C6 rat glioma cells," NeuroToxicology, vol. 33, no. 5, pp. 1128-1134, 2012.

[18] Z. Ji, D. Zhang, L. Li et al., "The hepatotoxicity of multi-walled carbon nanotubes in mice," Nanotechnology, vol. 20, no. 44, Article ID 445101, 2009.

[19] L. A. Mitchell, F. T. Lauer, S. W. Burchiel, and J. D. McDonald, "Mechanisms for how inhaled multiwalled carbon nanotubes suppress systemic immune function in mice," Nature Nanotechnology, vol. 4, no. 7, pp. 451-456, 2009.

[20] L. A. Mitchell, J. Gao, R. V. Wal, A. Gigliotti, S. W. Burchiel, and J. D. McDonald, "Pulmonary and systemic immune response to inhaled multiwalled carbon nanotubes," Toxicological Sciences, vol. 100, no. 1, pp. 203-214, 2007.

[21] L. Ma-Hock, S. Treumann, V. Strauss et al., "Inhalation toxicity of multiwall carbon nanotubes in rats exposed for 3 months," Toxicological Sciences, vol. 112, no. 2, pp. 468-481, 2009.

[22] J. P. Ryman-Rasmussen, M. F. Cesta, A. R. Brody et al., "Inhaled carbon nanotubes reach the subpleural tissue in mice," Nature Nanotechnology, vol. 4, no. 11, pp. 747-751, 2009.

[23] C. A. Beamer, T. A. Girtsman, B. P. Seaver et al., "IL-33 mediates multi-walled carbon nanotube (MWCNT)-induced airway hyper-reactivity via the mobilization of innate helper cells in the lung," Nanotoxicology, vol. 7, no. 6, pp. 1070-1081, 2013.

[24] D. W. Porter, A. F. Hubbs, B. T. Chen et al., "Acute pulmonary dose-responses to inhaled multi-walled carbon nanotubes," Nanotoxicology, vol. 7, no. 7, pp. 1179-1194, 2013.

[25] H. Suzuki, T. Toyooka, and Y. Ibuki, "Simple and easy method to evaluate uptake potential of nanoparticles in mammalian cells using a flow cytometric light scatter analysis," Environmental Science and Technology, vol. 41, no. 8, pp. 3018-3024, 2007.

[26] H. J. Phillips, "Dye exclusion tests for cell viability," in Tissue Culture: Methods and Applications, P. F. Kruse and M. J. Patterson, Eds., pp. 406-408, Academic Press, New York, NY, USA, 1973.

[27] C. P. Wan, E. Myung, and B. H. S. Lau, "An automated microfluorometric assay for monitoring oxidative burst activity of phagocytes," Journal of Immunological Methods, vol. 159, no. 1-2, pp. 131-138, 1993.

[28] M. R. Wilson, J. H. Lightbody, K. Donaldson, J. Sales, and V. Stone, "Interactions between ultrafine particles and transition metals in vivo and in vitro," Toxicology and Applied Pharmacology, vol. 184, no. 3, pp. 172-179, 2002.

[29] M. M. Bradford, "A rapid and sensitive method for the quantitation of microgram quantities of protein utilizing the principle of protein dye binding," Analytical Biochemistry, vol. 72, no. 1-2, pp. 248-254, 1976.

[30] G. L. Ellman, "Tissue sulfhydryl groups," Archives of Biochemistry and Biophysics, vol. 82, no. 1, pp. 70-77, 1959.

[31] H. G. Utley, F. Bernheim, and P. Hochstein, "Effect of sulfhydryl reagents on peroxidation in microsomes," Archives of Biochemistry and Biophysics, vol. 118, no. 1, pp. 29-32, 1967.

[32] A. K. Pandey, D. Gurbani, M. Bajpayee, D. Parmar, S. Ajmani, and A. Dhawan, "In silico studies with human DNA topoisomerase-II alpha to unravel the mechanism of in vitro genotoxicity of benzene and its metabolites," Mutation
Research/Fundamental and Molecular Mechanisms of Mutagenesis, vol. 661, no. 1-2, pp. 57-70, 2009.

[33] A. Dhawan and V. Sharma, "Toxicity assessment of nanomaterials: methods and challenges," Analytical and Bioanalytical Chemistry, vol. 398, no. 2, pp. 589-605, 2010.

[34] R. K. Shukla, A. Kumar, D. Gurbani, A. K. Pandey, S. Singh, and A. Dhawan, " $\mathrm{TiO}_{2}$ nanoparticles induce oxidative DNA damage and apoptosis in human liver cells," Nanotoxicology, vol. 7, no. 1, pp. 48-60, 2013.

[35] L. Yan, G. Li, S. Zhang et al., "Cytotoxicity and genotoxicity of multi-walled carbon nanotubes with human ocular cells," Chinese Science Bulletin, vol. 58, no. 19, pp. 2347-2352, 2013.

[36] A. R. Gliga, S. Skoglund, I. Odnevall Wallinder, B. Fadeel, and H. L. Karlsson, "Size-dependent cytotoxicity of silver nanoparticles in human lung cells: the role of cellular uptake, agglomeration and Ag release," Particle and Fibre Toxicology, vol. 11, no. 1, article 11, 17 pages, 2014.

[37] V. Sharma, D. Anderson, and A. Dhawan, "Zinc oxide nanoparticles induce oxidative DNA damage and ROS-triggered mitochondria mediated apoptosis in human liver cells (HepG2)," Apoptosis, vol. 17, no. 8, pp. 852-870, 2012.

[38] R. M. Adibhatla and J. F. Hatcher, "Lipid oxidation and peroxidation in CNS Health and disease: from molecular mechanisms to therapeutic opportunities," Antioxidants and Redox Signaling, vol. 12, no. 1, pp. 125-169, 2010.

[39] X. He, S.-H. Young, D. Schwegler-Berry, W. P. Chisholm, J. E. Fernback, and Q. Ma, "Multiwalled carbon nanotubes induce a fibrogenic response by stimulating reactive oxygen species production, activating NF- $\kappa \mathrm{B}$ signaling, and promoting fibroblast-to-myofibroblast transformation," Chemical Research in Toxicology, vol. 24, no. 12, pp. 2237-2248, 2011.

[40] A. R. N. Reddy, Y. N. Reddy, D. R. Krishna, and V. Himabindu, "Pulmonary toxicity assessment of multiwalled carbon nanotubes in rats following intratracheal instillation," Environmental Toxicology, vol. 27, no. 4, pp. 211-219, 2012.

[41] H. Sies, "Oxidative stress: from basic research to clinical application," The American Journal of Medicine, vol. 91, supplement 3, pp. S31-S38, 1991.

[42] H. Sies, "Glutathione and its role in cellular functions," Free Radical Biology and Medicine, vol. 27, no. 9-10, pp. 916-921, 1999.

[43] N. A. Denisova, I. Cantuti-Castelvetri, W. N. Hassan, K. E. Paulson, and J. A. Joseph, "Role of membrane lipids in regulation of vulnerability to oxidative stress in PC12 cells: implication for aging," Free Radical Biology and Medicine, vol. 30, no. 6, pp. 671678, 2001.

[44] M. Ahamed, R. Posgai, T. J. Gorey, M. Nielsen, S. M. Hussain, and J. J. Rowe, "Silver nanoparticles induced heat shock protein 70, oxidative stress and apoptosis in Drosophila melanogaster," Toxicology and Applied Pharmacology, vol. 242, no. 3, pp. 263$269,2010$.

[45] S. V. Lennon, S. J. Martin, and T. G. Cotter, "Dose-dependent induction of apoptosis in human tumour cell lines by widely diverging stimuli," Cell Proliferation, vol. 24, no. 2, pp. 203-214, 1991.

[46] M. I. Khan, A. Mohammad, G. Patil, S. A. H. Naqvi, L. K. S. Chauhan, and I. Ahmad, "Induction of ROS, mitochondrial damage and autophagy in lung epithelial cancer cells by iron oxide nanoparticles," Biomaterials, vol. 33, no. 5, pp. 1477-1488, 2012. 
[47] M. J. Piao, K. A. Kang, I. K. Lee et al., "Silver nanoparticles induce oxidative cell damage in human liver cells through inhibition of reduced glutathione and induction of mitochondriainvolved apoptosis," Toxicology Letters, vol. 201, no. 1, pp. 92100, 2011.

[48] A. J. Kowaltowski and A. E. Vercesi, "Mitochondrial damage induced by conditions of oxidative stress," Free Radical Biology and Medicine, vol. 26, no. 3-4, pp. 463-471, 1999.

[49] G. Kroemer, B. Dallaporta, and M. Resche-Rigon, "The mitochondrial death/life regulator in apoptosis and necrosis," Annual Review of Physiology, vol. 60, pp. 619-642, 1998.

[50] G. R. Martinez, A. P. M. Loureiro, S. A. Marques et al., "Oxidative and alkylating damage in DNA," Mutation ResearchReviews in Mutation Research, vol. 544, no. 2-3, pp. 115-127, 2003.

[51] L. Gonzalez, B. J. S. Sanderson, and M. Kirsch-Volders, "Adaptations of the in vitro MN assay for the genotoxicity assessment of nanomaterials," Mutagenesis, vol. 26, no. 1, pp. 185-191, 2011. 

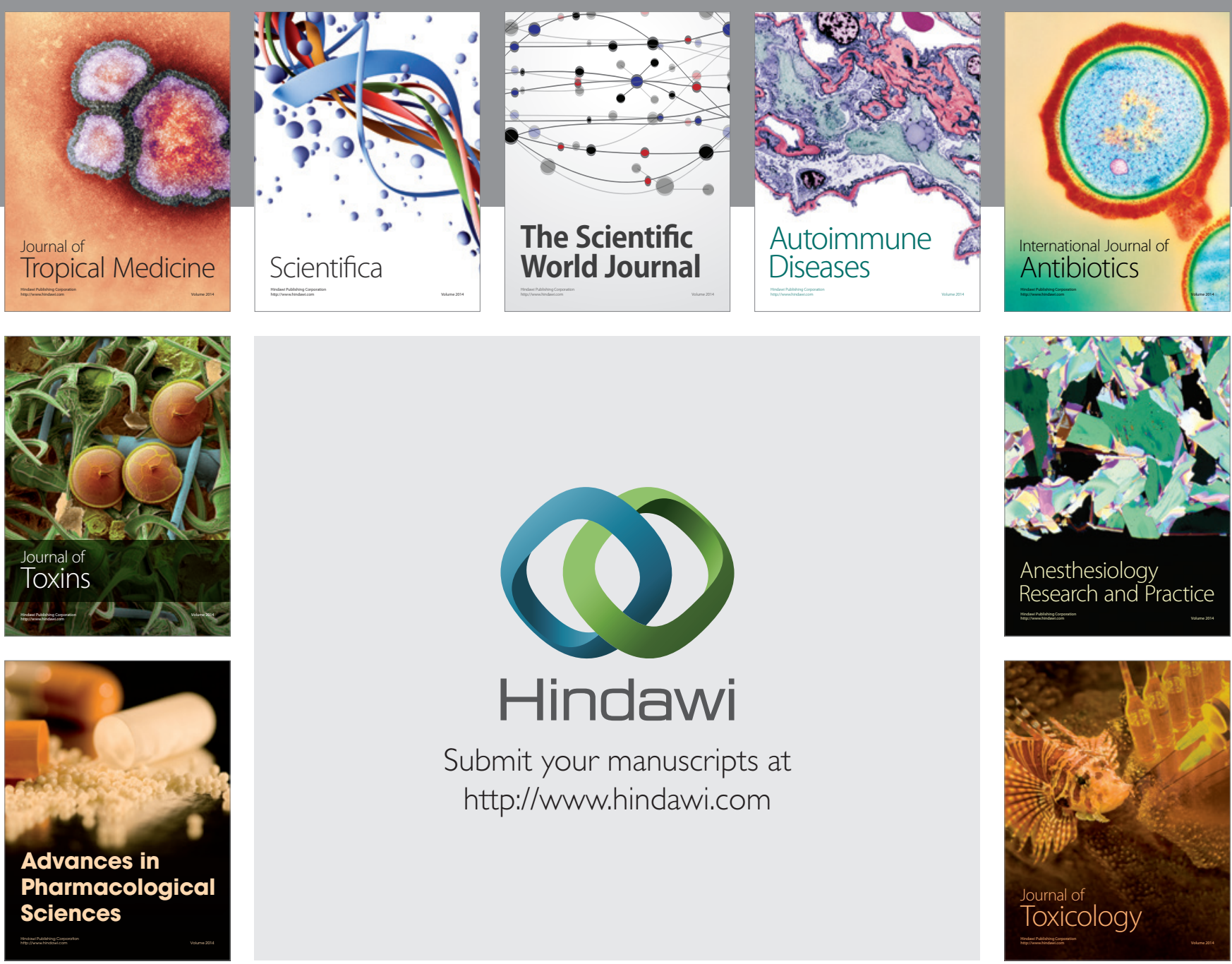

\section{Hindawi}

Submit your manuscripts at

http://www.hindawi.com
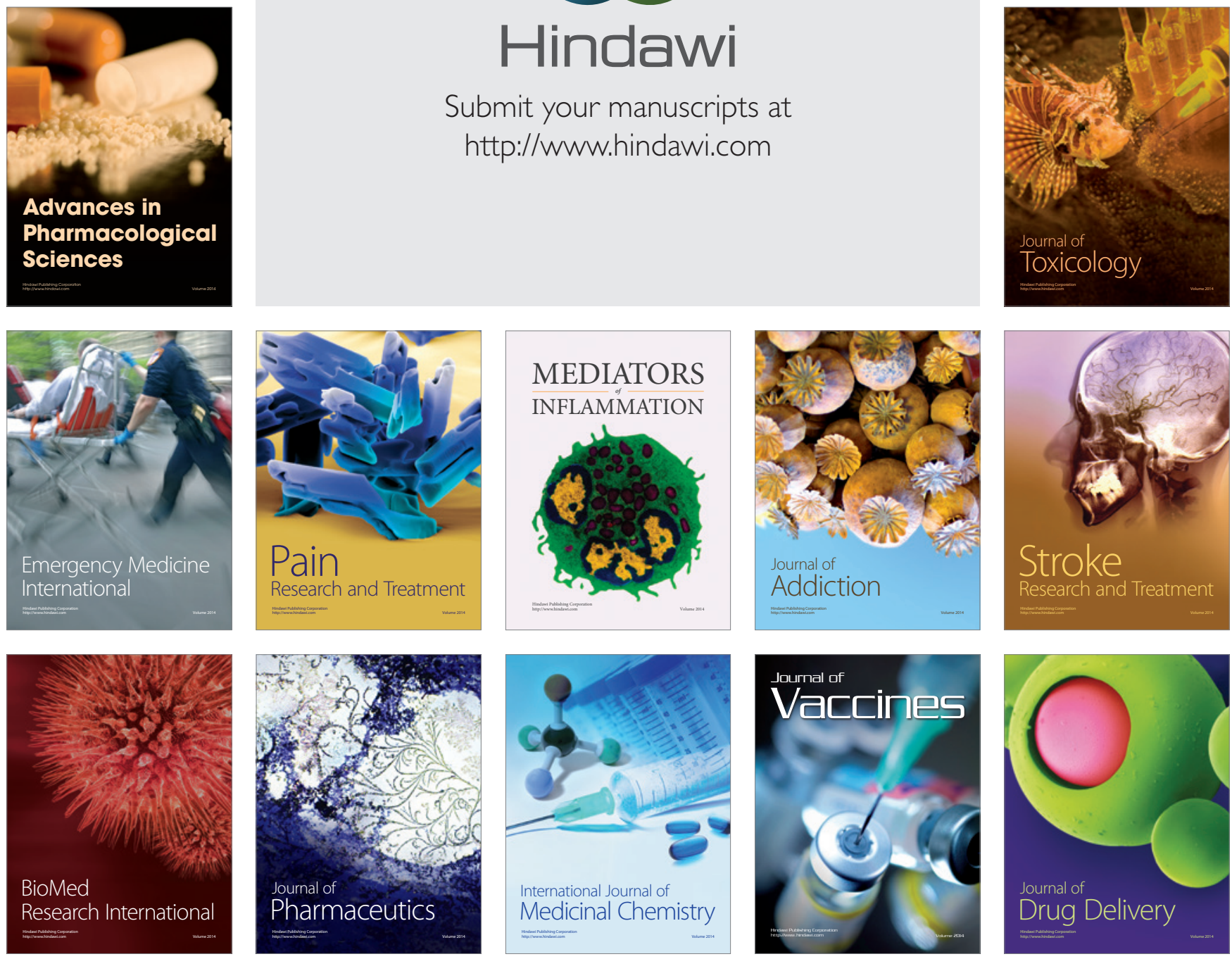